Article

\title{
Sustainable Consumption and Production: A Crucial Goal for Sustainable Development- Reflections on the Spanish SDG Implementation Report
}

\author{
Sandra Guevara ${ }^{1, *}$, Isabel Pla Julián ${ }^{2}$ \\ 1 Independent researcher and consultant, C/Comunidad de Madrid, 5 2C, \\ Barañáin 31010, Navarra, Spain \\ 2 Department of Applied Economics, Faculty of Economics, University of \\ Valencia, Avda. Tarongers, s/n, Valencia 46022, Spain \\ * Correspondence: Sandra Guevara, Email: sandraguevaram@gmail.com; \\ Tel.: +34-617337598
}

\begin{abstract}
The United Nations' Sustainable Development Goals (SDGs) have elicited multiple initiatives worldwide, aspiring to transform the world while leaving no one behind. As reports show, some advances have been made, although these are not sufficient to counter the challenges of global environmental, socio-economic and humanitarian crises. Transitioning toward sustainable development requires simultaneous progress in all 17 SDGs. These goals represent a comprehensive framework made up of interconnected, indivisible aspects, revealing the multidimensional nature of the task. This article focuses on SDG 12, the goal that aims to ensure sustainable consumption and production. Tackling the current patterns of consumption and production is crucial for sustainability because these are the main drivers of serious environmental and social impacts. Taking the European Union's conceptualisation of the circular economy as a reference, the article makes inroads into the transformation required to achieve this goal and interlinks it to the other 16 SDGs. Drawing on the Spanish Voluntary Report presented in 2018, the study shows the limitations in assessing progress with the tools available. Though we cannot generalise, the example of Spain provides insights of global interest. Achieving SDG 12 involves major transformations, including industrial processes and society as a whole. Evidently, this represents a huge challenge, as well as a great opportunity to foster sustainable development for policy-makers and stakeholders. Advancing towards this societal aspiration requires greater commitment in order to embrace change in a systemic and coherent way, enhancing the means of implementation and engaging all stakeholders.
\end{abstract}

\section{G open Access}

Received: 30 June 2019

Accepted: 16 October 2019

Published: 21 October 2019

Copyright $(02019$ by the author(s). Licensee Hapres, London, United Kingdom. This is an open access article distributed under the terms and conditions of Creative Commons Attribution 4.0 International License.

KEYWORDS: Sustainable Development; Sustainable Development Goals; socioecological systems; production and consumption patterns; sustainable consumption and production; circular economy; interactions 


\section{INTRODUCTION}

A new World Summit on Sustainable Development gathered in September 2019 to assess how far we have come in the implementation of the Sustainable Development Goals (SDGs) and the Agenda 2030, approved in 2015 [1]. These 17 goals constitute a societal aspiration for the wellbeing and prosperity of all people and countries, which includes basic needs, equality, fundamental freedoms, and peace and justice for all, whilst preserving the conditions that make life on Earth possible. This consensus on sustainable development (SD) is the result of an unprecedented process of collective action between governments, international organisations, advocacy movements and civil organisations, industry, global and local leaders, as well as scientists and experts.

The SDGs build upon the experiences of the Earth Summit that approved Agenda 21 and the 2000 Millennium Development Goals (MDGs) [2]. The latter aimed to improve the lives of the world's poorest people, whilst environmental concerns were at the top of the agenda at the Rio Summit, as shown by the Declaration of Principles, the Plan of Action and the agreements adopted in 1992 [3].

In spite of the remarkable progress achieved by the global mobilisation that the MDGs generated, inequalities persisted, and therefore a renewed commitment with a more integrated perspective was deemed necessary [4]. The SDGs constitute a more balanced and robust development agenda. Institutional and governance issues have been given a special place among the goals, as key enablers for SD.

Since the SDGs were approved, governments have begun to integrate them into their national agendas even though the SDGs remain legally non-binding. Notwithstanding these positive trends and the breadth of action and initiatives, the UN Secretary General recognises that the shift in development pathways to generate the transformation required to meet the SDGs by 2030 is not advancing at the speed or scale required [5].

Changing consumption and production patterns (CPPs) has re-emerged as a fundamental condition to uncouple economic productivity and environmental degradation. SDG 12 addresses this crucial aspect, and is the focus of this article. Previous studies have analysed SDG 12, showing that advancement towards sustainable CPPs would enable progress in many other areas of the SD agenda if approached from a systemic perspective [6], an imperative for the achievement of SD [7]. This article aims to understand the transformations SDG 12 entails, and the challenges that have to be overcome in order to move forward on this path based on the European approach to the circular economy. Taking Spanish implementation of SDG 12 as an example, we delve into the kinds of changes promoted by each of its targets, and where we are heading according to the data for the corresponding indicators. These aspects also illuminate interlinkages with other goals as well as the challenges that lie ahead. 
The time has come to reassess the direction of the SDGs. Based on data from all 193 UN Member States, the SDG Index and Dashboard Report 2018 [8] found that no country is on track to achieving the SDGs. Even countries at the top of the 2018 SDG Index (Sweden, Denmark and Finland) need to significantly fast-track progress towards crucial goals such as SDG 12 (and SDG 13, Climate Action).

The 2019 edition of the Sustainable Development Report and SDG Index and Dashboard [9] highlights that we are losing ground in many areas, eroding the very foundations of our economies and livelihoods while inequalities continue to grow around the world.

However, the potential of the SDGs to drive progress has been questioned. Spangenberg [10] analysed the coherence of the goals and found that they focus on state and impact, neglecting pressures and supporting counterproductive drivers. One of the salient positive drivers are sustainable CPPs, which require urgent attention and decisive commitment. The aim of this article is to analyse SDG 12 (ensuring sustainable consumption and production), taking its implementation in Spain as an example. The purpose is to reflect on the kind of transformations that this goal fosters, and to study its progress and the impact it has on the rest of the Agenda 2030. The following Section "MATERIALS AND METHODS" presents the methodology followed for the study, and, the conceptual bases are set forth in the literature review. Subsequently, Section "RESULTS OF THE ANALYSIS OF THE SDG 12" is divided into two parts: the analysis of SDG 12 and each of its targets, followed by a study of how it interacts with the rest of the SDGs. The last section sets out our conclusions.

\section{MATERIALS AND METHODS}

The first part of our research required analysing the literature on Sustainable Development. It led us to look into its background and evolution up until the approval of the SDGs in 2015. We also studied CPPs as a fundamental requirement for SD, and proposals to bring them into line with the functioning of ecosystems.

The second part of the research focused on the analysis, scope and implications of SDG 12, bearing in mind the kind of changes required by sustainable CPPs. Given the fact that Spain is currently working on its National Circular Economy Strategy, underpinned by the corresponding European Union (EU) policy, this conceptual framework served as a reference to understand the scope of the task. We inquired about the kind of transformations that each SDG 12 target involves. We also reviewed the monitoring indicators that enabled us to grasp the significance of the targets.

In order to facilitate an in-depth analysis of the potential effectiveness of the Agenda 2030, we chose to look at a specific example, taking the latest Voluntary Report on SDG implementation presented by Spain in 2018 as the main source of information to perform this exercise. 
To study the interactions, we evaluated each of the SDG 12 targets against the 16 other goals and the remaining 158 targets. The question posed, in this case, aimed to identify whether the data on the selected target revealed any progress. Then, we checked the interactions to see whether making progress toward each of the SDG 12 targets would have an impact on the ability to make progress toward the other 16 goals or vice versa. This process revealed the relevance of complex system thinking to understand and manage the different aspects involved in SDG 12 and its impacts on the rest of the development agenda.

\section{Literature Review}

The analysis of the SDGs takes us back to a longstanding debate on the meaning of Sustainable Development. The concept emerged amidst a debate on the serious consequences of an economic model that has ignored the material base that supports it $[11,12]$, generating a long-term systemic perspective integrating social, environmental and economic concerns.

The term SD first appeared in the World Conservation Strategy: Living resource conservation for Sustainable Development, prepared by the International Union for the Conservation of Nature [13], which underlined the need to come to terms with resource limitations and the carrying capacities of ecosystems. Evidently, its focus was predominantly ecological sustainability. Nevertheless, the concept gained popularity and broader understanding as a result of its inclusion in the Brundtland Report, published in 1987 [14].

SD needs to be understood not only as a concept in itself, but also as a social and political construct [15]. Some of the political and distributive issues involved in SD and its underlying complexities [16] came to light in the SDGs. Since the SD concept emerged, three fundamental aspects have been highlighted: the balance between economic, social and environmental dimensions, the need for long-term vision, and the compelling need for global justice. In other words, a strategic approach is essential for SD and one of the characteristics of good governance.

The need for addressing the economic pillar of sustainability has been long understood. In 1966, Boulding [17] called for a new economy in tune with the cyclical ecological system in order to preserve nature, which provides us with the resources and services that are essential for the survival of our civilisation. The prevailing industrial model that is characterised by a linear approach (take-make-use-dispose), generates significant social and environmental impacts while pursuing economic growth with complete disregard for the planet's carrying capacity. This has been possible owing to a relatively abundant stock of natural resources, enormous amounts of cheap energy and the perception that science is capable of generating substitute materials and ensuring adaptation to the changes brought about in ecosystems as a consequence of their exploitation [18]. 
Concerns about the serious environmental challenges at stake have led to the emergence of a number of proposals and approaches. Recently, rethinking the life cycle of products as loops has gained relevance. This approach is known as cradle to cradle [19], meaning that products do not generate waste since they serve as the input for other production processes, as do nutrients in nature. The proposal is to design products for effectiveness with a positive impact instead of focusing on reducing negative impacts. Doing good is not the same as doing the wrong things less badly. Stahel and Reday [20] state that replicating nature's efficiency would generate business opportunities with a positive social and environmental impact (increased employment and economic competitiveness, resource consumption and waste prevention). Pearce and Turner [21] coined the term the Circular Economy (CE), although studies about the concept date back to the 18th century [22]. For the European Union (EU), the CE represents a development strategy that enables economic growth while optimising the consumption of natural resources through a profound transformation of production chains and consumption patterns, and the re-designing of industrial systems [23]. The $\mathrm{CE}$ involves adapting production processes and designing products and services to minimise energy consumption and use of resources, and to foster the reuse, recovery and recyclability of materials. At the same time, it designs out waste, turns waste into resources, and adds value to the materials that close the loop.

Restructuring industrial processes also has to do with people, and thus it is important to take all stakeholders into account and engage them (workers, consumers, whose habits and choices influence production patterns and have a major environmental impact; decision-makers in the private and the public sector; non-governmental organisations; teachers educating for SD and the media, which shapes opinions and has a huge capacity to influence people's behaviours, among others). Transforming complex socio-ecological systems-a term coined by Berkes \& Folke in 1998 [24] as a way to illustrate the complex and adaptive systems formed by biophysical and social factors interacting continuously, where multiple interactions take place at the same time, within and outside a system, needs to be managed as a whole [25].

This systemic perspective is crucial for the SDGs. Interactions between and among goals can be mutually reinforcing or, on the other hand, can generate conflict [26]. A body of literature has been developed, exploring linkages between SDGs and targets, as well as the coherence and strength of the indicators. A study by Pradham et al. [27] concluded that SDG 1 depicts synergies with most goals, while SDG 12 shows trade-offs. They argue that synergies between goals can be leveraged and that trade-offs need to be overcome by deeper changes in current strategies. The interactions and interdependencies between goals and targets show that sustainable development goes beyond the local, regional or national perception of our realities to reach a global level. 
The approval of the SDGs represents a renewed commitment to achieve SD that has brought the essential question of sustainable consumption and production back to the international development agenda. This issue had already been addressed by Agenda 21 and a body of knowledge about this topic has been developed, particularly in the last decade. Nevertheless, there is no consensus on the systemic scope of the transformations the term implies. According to the UNEP [28] the key principles of SPCs are: (a) improving people's quality of life without increasing environmental degradation and without compromising resource needs of future generations; (b) decoupling economic growth from environmental degradation; (c) applying life-cycle analysis considering the impacts from all stages of the production and consumption process; and (d) avoiding the rebound effect, where efficiency gains are cancelled out by resulting increases in consumption.

Unfortunately, about half of the indicators that the Inter-Agency Expert Group on SDG indicators (IAEG-SDG indicators) approved to monitor progress on the SDGs, including CPPs, lack acceptable country coverage or agreement on their methodologies. This group [29] divided the indicators into three levels: Tier 1 (Indicator is conceptually clear, has an internationally established methodology and standards are available, and data are regularly produced by at least $50 \%$ of countries) contains 104 indicators; Tier 2 (like Tier 1 but without regularly produced data) has 88 indicators; and Tier 3 (those lacking established methodology and standards) has 34 indicators. In addition, there are five indicators in multiple tiers, since different components of the indicators are classified into different tiers.

\section{RESULTS OF THE ANALYSIS OF SDG 12}

\section{Targets and Indicators}

It is important to recall that Agenda 2030 does not include any explicit definition of sustainable consumption and production (SCP), apart from the commitment to undertake fundamental changes in the way our societies produce and consume goods and services, as stated in the introductory section. The absence of a clear definition has led to different interpretations which have impacts on the scope of transformations and the attainment of the goals.

Table 1 shows that SDG 12 has eight main targets in addition to the three targets called "means of implementation, with the 14 corresponding indicators that will be analysed in this section. Additionally, the table includes the classification of each indicator and the data from the latest Spanish Voluntary Report (SVR) presented in 2018 [30]. 
Table 1. Spanish data on the SDG12.

\begin{tabular}{|c|c|c|c|}
\hline \multicolumn{4}{|c|}{ Sustainable Development Goal 12: Ensure sustainable consumption and production patterns } \\
\hline Target & Indicator & Classification & Spain \\
\hline 12.1 & $\begin{array}{l}\text { 12.1.1 Number of countries with sustainable consumption } \\
\text { and production (SCP) national action plans or SCP } \\
\text { mainstreamed as a priority or a target into national policies }\end{array}$ & Tier II & $\begin{array}{l}\text { The data is presented by the } \\
\text { corresponding UN agency. }\end{array}$ \\
\hline \multirow[b]{2}{*}{12.2} & $\begin{array}{l}\text { 12.2.1 Material footprint, material footprint per capita, and } \\
\text { material footprint per GDP }\end{array}$ & $\begin{array}{l}\text { Tier II (Same as } \\
\text { 8.4.1) }\end{array}$ & No data. \\
\hline & $\begin{array}{l}\text { 12.2.2 Domestic material consumption (DMC), domestic } \\
\text { material consumption per capita, and domestic material } \\
\text { consumption per GDP } \\
\text { Agreed methodology: } \\
\text { DMC = Imports + Domestic Extract - Exports }\end{array}$ & $\begin{array}{l}\text { Tier I (Same as } \\
8.4 .2 \text { ) }\end{array}$ & $\begin{aligned} & \text { 2015: } \\
& \text { - } 406,561,982 \text { tons } \\
& \text { - } 8.76 \text { tons/per capita } \\
& \text { - } 379.71 \text { tons/mill€ } \\
& \text { 2016: } \\
& \text { - } 402,789,351 \text { tons } \\
& \text { - } 8.67 \text { tons/per capita } \\
& \text { - } 364.26 \text { tons/mill€ } \\
&\end{aligned}$ \\
\hline 12.3 & 12.3.1 (a) Food loss index and (b) food waste index & $\begin{array}{l}\text { 12.3.1 a Tier II; } \\
\text { 12.3.1 b Tier III }\end{array}$ & $\begin{array}{l}\text { Partial data on households; } \\
1.2 \text { billion } \mathrm{kg} / \text { year (2017) } \\
\text { EU is working on a methodology. }\end{array}$ \\
\hline \multirow[b]{2}{*}{12.4} & $\begin{array}{l}\text { 12.4.1 Number of parties to international multilateral } \\
\text { environmental agreements on hazardous waste and other } \\
\text { chemicals that meet their commitments and obligations in } \\
\text { transmitting information as required by each relevant } \\
\text { agreement }\end{array}$ & Tier I & $\begin{array}{l}\text { According to the report, Spain has } \\
100 \% \text { compliance with the Basel } \\
\text { Convention, Montreal Protocol, } \\
\text { Rotterdam Agreement, and Stockholm } \\
\text { agreement. }\end{array}$ \\
\hline & $\begin{array}{l}\text { 12.4.2 Hazardous waste generated per capita and } \\
\text { proportion of hazardous waste treated, by type of } \\
\text { treatment. }\end{array}$ & Tier III & $\begin{array}{l}\text { Hazardous waste in } 2016 \\
\text { - } \quad \text { Generated pc: } 61 \text { tons } \\
\text { - } \quad \text { Treated: 2,321,536 tons } \\
\text { - } \quad \text { Recovered: } 71.46 \% \\
\text { - } \quad \text { Safely landfilled: } 22.61 \% \\
\text { - Incinerated: } 5.93 \% \\
\text { Other surveys for the Environmental } \\
\text { Indicators' public data: } \\
\text { - } \quad \text { Generated: } 2.56 \text { mill. tons } \\
\text { - } \quad \text { Recovered: } 71.4 \% \\
\text { - } \quad \text { Safely landfilled: } 22.1 \% \\
\text { - } \quad \text { Incinerated: } 6.5 \%\end{array}$ \\
\hline 12.5 & 12.5.1 National recycling rate, tons of material recycled & Tier III & $\begin{aligned} & \text { Municipal waste: } \\
& 2012 \\
& \text { - } \text { Safely Landfilled: } 46 \% \\
& \text { - } \text { Recovered (recycling): } 47 \% \\
& 2014 \\
& \text { - } \text { Safely Landfilled: } 46 \% \\
& \text { - } \text { Recovered (recycling): } 46 \% \\
&\end{aligned}$ \\
\hline 12.6 & $\begin{array}{l}\text { 12.6.1 Number of companies publishing sustainability } \\
\text { reports }\end{array}$ & Tier III & $\begin{array}{l}\text { 2015: } 959 \\
\text { 2016: } 925\end{array}$ \\
\hline
\end{tabular}


Table 1. Cont.

\begin{tabular}{|l|l|l|l|}
\hline \multicolumn{5}{|c|}{ Sustainable Development Goal 12: Ensure sustainable consumption and production patterns } \\
\hline Target & Indicator & Classification & Spain \\
\hline 12.7 & $\begin{array}{l}\text { 12.7.1 Number of countries implementing sustainable } \\
\text { public procurement policies and action plans }\end{array}$ & Tier III & No data \\
\hline 12.8 & $\begin{array}{l}\text { Extent to which (i) global citizenship education and (ii) } \\
\text { education for sustainable development (including climate } \\
\text { change education) are mainstreamed in (a) national } \\
\text { education policies; (b) curricula; (c) teacher education; and } \\
\text { (d) student assessment }\end{array}$ & Tier III & No data \\
\hline $12 . \mathrm{a}$ & $\begin{array}{l}\text { 12.a.1 Amount of support to developing countries on } \\
\text { research and development for SCP and environmentally } \\
\text { sound technologies }\end{array}$ & Tier III & 2016: € 953,843.51504 \\
\hline $12 . b$ & $\begin{array}{l}\text { 12.b.1 Number of sustainable tourism strategies or policies } \\
\text { and implemented action plans with agreed monitoring and } \\
\text { evaluation tools }\end{array}$ & $\begin{array}{l}\text { Tier III } \\
\text { (production and consumption) and as a proportion of total } \\
\text { national expenditure on fossil fuels }\end{array}$ & Tier II \\
\hline $12 . c$
\end{tabular}

Source of data: Spanish voluntary report 2018 \& the UNSTATS Tier Classification for global SDG indicators (May 2019).

Out of the SDG 12 indicators, only two belong to Tier I. Hence, only in these two cases is the indicator conceptually clear, has an internationally established methodology and available standards, while at least $50 \%$ of the countries are producing data on this particular issue. Four other indicators have been classified as Tier II, meaning that the indicator is conceptually clear, that it has an internationally established methodology and standards are available, but that data is not regularly produced by countries. The other eight indicators correspond to Tier III, since no internationally established methodology or standards are yet available. The first conclusion that can be drawn from this classification is not very encouraging. Four years after SDG approval, there is still no clear indication on what we have to measure to assess progress for most of the SDG 12 targets.

Spain follows this monitoring system established by the IAEG-SDG indicators, in addition to the European system. EUROSTAT has identified 100 SDG indicators for the European Union, with 56 of them coinciding with the global UN indicators. The following indicators are used for SDG 12: (1) consumption of toxic chemicals; (2) resource productivity and domestic material consumption; (3) average of $\mathrm{CO}_{2}$ emissions per $\mathrm{Km}$ from new passenger cars; (4) circular material use rate (recovered material that has been reintroduced into the economy); (5) generation of waste excluding major mineral wastes; and (6) recycling rate of waste, excluding major minerals [31]. The government of Spain has established additional indicators to adapt monitoring to the specific Spanish context. 
A look into the transformations entailed by the targets revealed that target 12.1 called for the implementation of the 10 Year Framework of Programmes on Sustainable Consumption \& Production (10YFP) adopted at the United Nations Conference on Sustainable Development in June 2012, also known as Río+20 [32]. This framework aims to support regional and national policies and initiatives in five areas: (1) sustainable food systems and consumer information; (2) sustainable lifestyles and education; (3) sustainable public procurement; (4) sustainable buildings and construction; and (5) sustainable tourism, including ecotourism. So far, the programmes have generated a series of collaborative projects and capacity-building initiatives, but not deep systemic changes in the way we produce and consume.

The indicator to monitor progress of target 12.1 is the number of countries with SCP national action plans or SCP mainstreamed as a priority or a target in national policies, which says nothing about the impact that these policies generate, whether the plans have been implemented, or even more importantly the scope of any systemic transformation.

The 2018 SVR indicates that Spain is immersed in the process of drawing up a national CE strategy as a result of the adoption of the Circular Economy Action Plan by the European Union in 2015. Taking into account that the CE aims at sustainable production processes that make it possible to maximise available resources both in terms of materials and energy, the interpretation of the task ahead entails a deep transformation. Instead of focusing on eco-efficiency, which is reiterated throughout the whole Agenda 2030 and the 10YFP, it aims at eco-effectiveness, which proposes the transformation of products and their associated material flows in a way that is supportive for ecological systems [33]. Another positive impact of the $\mathrm{CE}$ is the generation of new capacities, new business models, the creation of new jobs and the generation of environmental, economic and social value. It is obviously not a panacea, however, because the model needs to enhance both the social dimension of production processes and the consumption dimension [34].

The CE monitoring framework [35] tracks key trends and patterns to understand how the various elements of this industrial model are developing. It comprises ten key indicators, which cover production, consumption, waste management and secondary raw materials, as well as economic aspects (investments, jobs, gross value added and innovation). Among other key indicators, the circular (secondary) use of material in Spain was 8.2\% in 2016 (EU-28 average 11.7\%), down from 10.4\% in 2010. By contrast, Spain performs above the EU-28 average in the number of persons employed in the CE (2.02\% of total employment in 2016 compared to the EU-28 average of 1.73\%). This information is not enough to assess global progress on all the aspects that are involved in a CE strategy. In fact, the government has announced that the National CE Strategy would be approved in 2018, yet it seems to be on hold. Though there have been other 
moves towards the $\mathrm{CE}$ by regional authorities, it is not clear to what extent Spain is actually making progress in this area.

Target 12.2 aims to achieve sustainable management and efficient use of natural resources. Again, it makes a reference to efficiency. The corresponding indicator measures the material footprint of a country or region (per capita and with regard to its GDP), as well as its domestic material consumption. The first concept denotes the total amount of raw materials extracted globally (across the entire supply chain) to meet that economy's final consumption demand.

Implementing $\mathrm{CE}$ principles would enable more sustainable resource management and value generation, reducing environmental pressure and impacts. The statistical annex of the 2018 SVR does not include any data on the first indicator of this target, though it does include information about the second one. As shown in the last column of Table 1, Spanish domestic material consumption decreased in comparison to 2014, both in absolute and relative terms, in the context of economic recovery. This is a positive sign.

Target 12.3 aspires to reduce food waste and food loss by $50 \%$ in 2030 , the only numeric objective in the SDG 12 targets. Food waste is today estimated at between $30 \%$ and $50 \%$ of all food produced at different stages of the supply chain [36]. The indicators used to monitor this target are the food loss index and the food waste index. However, it addresses the impact but not the causes, and therefore does not suggest means to achieve these reductions. Spain indicates in its report that the country has partial data on food loss in households, not other sectors. Again, the SVR provides no indication of progress.

Target 12.4, which aims to achieve sound management of chemicals and wastes throughout their life cycle, is monitored by two indicators. First, compliance with multilateral environmental agreements (MEAs) on hazardous waste and other chemicals, as well as the quantity of hazardous waste generated and treated. It is fair to believe that the member countries which signed these MEAs would be following the agreed practices, but this is not always the case. Spain states that it complies $100 \%$ with the Basel agreement and other related MEAs. Nevertheless, the proportion of hazardous wastes treated (per capita) is not an indication that the system is reducing these substances in production processes, but that they are adequately treated afterwards. Thus, monitoring generation in parallel has been required to complement this information. According to its 2018 report, Spain reduced its generation of hazardous waste per capita.

Target 12.5 aims to decrease waste generation through prevention, reduction, recycling and reuse. Thus, it suggests a transformation along the lines of the $\mathrm{CE}$ conceptualisation, yet contains nothing specific. In addition, the indicator used to monitor the target only measures the recycling rate. Indeed, estimating waste prevention is a complex task, although it is the fundamental aspect to address, rather than to increase recycling, which is costly, generates less value with the exception of 
upcycling, and can indicate uncontrolled consumption. According to the SVR, the rate of municipal waste that Spain recycled between 2012 and 2014 was constant at $46 \%$. Thus, the monitoring system does not show a transformation, but the status of recycling at a particular time.

Target 12.6 aims to encourage sustainable practices and to integrate them into the reporting cycle. While this is positive, there are different methodologies to communicate sustainability practices so it is not necessarily an indication that companies are comprehensively changing their CPPs. Furthermore, the emphasis of the target is on large companies, whereas, in Spain for instance, small and medium enterprises represent around $95 \%$ of the total private sector, generating half of the employment. In addition, there is a general distrust concerning the effectiveness of these reports. Progress for this target is tracked by the number of companies publishing sustainability reports, yet the latest SVR indicates that in Spain the number of companies issuing these reports went down from 959 companies in 2015, to 925 in 2016.

Target 12.7 calls for promoting sustainable public procurement. In general, this target refers to taking social and environmental considerations into account when exercising procurement instead of just economic parameters. It translates into buying reduced-energy consumption goods, products that have been made without child labour or out of recycled materials, etc. The European Union has published a Guide on Circular Public Procurement [37] in order to contribute to closing the energy and material loops whilst minimising and avoiding negative environmental impacts and waste generation throughout the life-cycle of works, goods and services purchased. The corresponding indicator measures the number of countries implementing sustainable public procurement policies and action plans. Consequently, Spain could be included in the UN's global statistics if just a few local governments reported on their sustainable procurement practices. The 2018 SVR does not provide any data, although positive initiatives are being taken in this area.

Target 12.8's aim is to engage people in the attainment of this change in CPPs by giving them relevant information on SD and on lifestyles in harmony with nature. In fact, we human beings are the primary beneficiaries of preserving the conditions that make life possible on Earth. We represent the consumer side of SDG 12, and therefore we have a relevant role to play. It is crucial to make informed decisions about consumption, use and disposal of products, and to exercise our purchasing power to support sustainable businesses. At the same time, the democratisation of communication means citizens can also be information providers and can promote sustainable life styles themselves, but this role has not been included in the target. The indicator, in Tier III, refers to the extent to which global citizenship education and education for SD are mainstream in national education policies, curricula, teacher education, and student assessment. Hence, the aim is to assess the 
situation in the education sector but without establishing a benchmark. Spain did not include any data concerning this target. The three means of implementation targets (12.a, 12.b, and 12.c) address different aspects that would contribute to achieving SDG 12. The first one highlights the need to support developing countries so they can strengthen their scientific and technological capacities and can move towards more sustainable CPPs. The global scale of environmental and socio-economic challenges highlights the relevance of this target. Nevertheless, attaining it is a complex task, and differences in priorities and approaches represent a great challenge. The indicator measures the state of research and development aid. According to the 2018 SVR, Spain's official aid for this purpose amounted to $€ 953,843.50$ in 2016.

Target 12.b aims to develop and to implement tools to monitor impacts, especially on Sustainable Tourism. This is clearly a very important objective connected to target 12.1, given that 10YFP has a specific tourism programme centred on developing sustainable CPPs especially adapted to this sector. Tourism is a fundamental economic sector for Spain and has a significant impact on the environment. Salient examples include the construction of tourist accommodations in coastal areas, the generation of plastic waste, and $\mathrm{CO}_{2}$ emissions, among others. The corresponding indicator measures the number of sustainable tourism strategies, policies, and implemented action plans with agreed monitoring and evaluation tools. It is interesting to note that the reference to action plans is to "implemented" action plans, though the monitoring and evaluation tools are yet to be developed. The 2018 SVR shows no data on this target. Nevertheless, Spain is developing a national strategy on sustainable tourism aimed at transforming the sector. And last but not least, target 12.c requires the rationalisation of "inefficient" fossil-fuel subsidies, a key aspect of serious environmental problems such as climate change. The amount of money that goes into these subsidies could serve to fund global access to energy. Fossil fuel subsidies are drivers of distortions in the energy market. Indicator 12.c.1 measures the magnitude of the problem (amount of fossil fuel subsidies per unit of GDP and as a proportion of total national expenditure on fossil fuels), but does not encourage a reduction of those subsidies on the grounds of differences in the situations of different countries.

\section{Interactions}

The analysis of target 12.1 shows some kind of interaction with almost all the rest of the goals of the Agenda 2030, as shown in Table 2. Sustainable CPPs would contribute to reducing greenhouse gas emissions, addressing one of the main causes of extreme climate-related events (1.5); to enhancing the sustainability of food production systems (2.4), and to improving value creation (2.3); to improving health by reducing air, water and soil pollution (3.9); to ensuring effective participation and equal opportunities to women in enterprises, given that sustainable CPPs also 
include social aspects (5.5); to improving water quality by reducing pollution and dumping and minimising the release of hazardous chemicals and materials (6.3); to increasing water efficiency (6.4) and to implementing integrated water resource management (6.5); to increasing the share of renewable energy in production and consumption (7.2), to improving energy efficiency (7.3); to promoting decent job creation (8.3); to decoupling economic growth from environmental degradation (8.4); to eradicating forced labour (8.7); to promoting safe and secure working environments (8.8); to promoting inclusive and sustainable industrialisation (9.2); to improving the sustainability of infrastructure industries (9.4); to ensuring equal opportunities and to avoiding inequalities in firms (10.3); to making transportation (11.2) and urbanisation (11.3) sustainable; to strengthening resilience and adaptive capacity with respect to climate-related hazards (13.1); to integrating climate change in firm strategies (13.2); to reducing marine pollution (14.1) to minimising ocean acidification (14.3); to making sustainable use of terrestrial and inland freshwater ecosystems and their services (15.1); to practicing fair and equitable sharing of benefits arising from the utilisation of genetic resources (15.6); to eradicating corruption and bribery as business practices (16.5); and to introducing accountability and transparency (16.6), among other effects.

On the other hand, enhancing policy coherence for sustainable development (17.14) is crucial for sustainable CPP and the attainment of the entire Agenda 2030. Building resilient infrastructure (9.1) and upgrading infrastructure to make it sustainable (9.4) would contribute to attaining target 12.1. Enhancing scientific research and the technological capabilities of industrial sectors to foster innovation (9.5) is a fundamental prerequisite for achieving sustainable CPP. Conversely, sustained per capita economic growth (8.1) increases consumption and production impacts. This raises doubts as to the coherence of the agenda, even if we understand the political reasoning behind it.

Target 12.2 interacts directly with SDG 6. Achieving sustainable management and efficient use of natural resources would have an impact on the aspiration to universal and equitable access to safe and affordable drinking water for all (6.1), water quality (6.3), water-use efficiency (6.4), integrated water resource management and the protection and restoration of water-related ecosystems (6.6).

Target 12.3 addresses the shameful problem of food waste. Although the means of implementation are not clear, its achievement would contribute to ending hunger (2.1) and to reducing the adverse impact of cities (11.6). Besides, reducing food loss in production and supply chains, the other aim of this target, is linked to agricultural productivity (2.3) and the possibility of adding value to commodities (9.b). 
Table 2. Interlinks between SG12 targets and the other 16 SDGs.

\begin{tabular}{|c|c|c|c|c|c|c|c|c|c|c|c|}
\hline 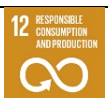 & 12.1 & 12.2 & 12.3 & 12.4 & 12.5 & 12.6 & 12.7 & 12.8 & 12.a & 12.b & 12.c \\
\hline 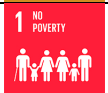 & 1.5 & & & & & & & & 1.4 & & 1.4 \\
\hline 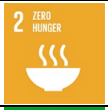 & $\begin{array}{l}2.3 \\
2.4 \\
\end{array}$ & & $\begin{array}{l}2.1 \\
2.3 \\
\end{array}$ & & & 2.4 & $\begin{array}{l}2.4 \\
2.5\end{array}$ & & 2.a & 2.3 & \\
\hline$-1 \sqrt{6}$ & 3.9 & & & 3.9 & & 3.9 & 3.9 & & & & \\
\hline | & & & & & & 4.4 & $\begin{array}{l}4.1 \\
4.5 \\
4 . b \\
\end{array}$ & 4.7 & $\begin{array}{l}\text { 4.b } \\
4 . c\end{array}$ & & \\
\hline ๑ & $\begin{array}{l}5.1 \\
5.2 \\
5.5 \\
\end{array}$ & & & & & 5.1 & 5.5 & 5.b & & & \\
\hline 6 & $\begin{array}{l}6.3 \\
6.4 \\
6.5 \\
\end{array}$ & $\begin{array}{c}6.1 / 6.3 \\
6.4 / 6.5 \\
6.6 \\
\end{array}$ & & 6.3 & 6.3 & $\begin{array}{l}6.6 \\
6 . b\end{array}$ & $\begin{array}{l}6.3 \\
6.4 \\
6.5 \\
\end{array}$ & & 6.a & & \\
\hline $\begin{array}{l}7 \text { ath } \\
= \\
=\end{array}$ & $\begin{array}{l}7.2 \\
7.3\end{array}$ & & & & 7.3 & 7.3 & 8.4 & & $\begin{array}{c}7.1 \\
7.2 / 7.3 \\
\text { 7.a/7.b } \\
\end{array}$ & & 7.1 \\
\hline 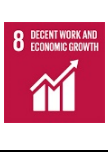 & $\begin{array}{c}8.1 \\
8.3 / 8.4 \\
8.7 / 8.8 \\
\end{array}$ & 8.2 & & & 8.4 & $\begin{array}{l}8.5 \\
8.7 \\
8.8 \\
\end{array}$ & & & & 8.9 & \\
\hline 9 & $\begin{array}{c}9.1 \\
9.2 \\
9.4 / 9.5\end{array}$ & $\begin{array}{l}9.4 \\
9 . b\end{array}$ & 9.b & & & 9.2 & & 9.c & $\begin{array}{l}9.5 \\
9 . \mathrm{a} \\
9 . \mathrm{c}\end{array}$ & & \\
\hline 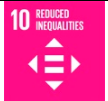 & 10.3 & & & & & & & & & & \\
\hline 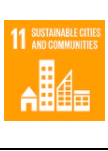 & $\begin{array}{l}11.2 \\
11.3\end{array}$ & $\begin{array}{l}11.5 \\
11.6 \\
11 . b\end{array}$ & 11.6 & 11.6 & & $\begin{array}{l}11.2 \\
11.4\end{array}$ & & & 11.c & 11.4 & \\
\hline 13 & $\begin{array}{l}13.1 \\
13.2 \\
\end{array}$ & & & & & & & 13.3 & 13.b & & $\begin{array}{l}13.1 \\
13.2 \\
\end{array}$ \\
\hline 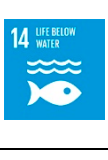 & $\begin{array}{l}14.1 \\
14.3\end{array}$ & $\begin{array}{l}14.1 \\
14.2 \\
14.3 \\
\end{array}$ & & $\begin{array}{l}14.1 \\
14.3\end{array}$ & 14.1 & $\begin{array}{c}14.1 \text { to } \\
14.5\end{array}$ & 14.2 & & 14.b & 14.7 & \\
\hline 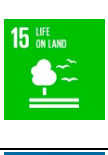 & $\begin{array}{l}15.1 \\
15.6\end{array}$ & $\begin{array}{l}15.1 \\
15.2\end{array}$ & & & & $\begin{array}{l}15.1 \\
15.2 \\
15.3 \\
\end{array}$ & 15.2 & & & $\begin{array}{l}15.7 \\
15.8 \\
15 . c\end{array}$ & \\
\hline 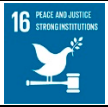 & $\begin{array}{l}16.5 \\
16.6\end{array}$ & & & & & $\begin{array}{l}16.6 \\
16.7\end{array}$ & & 16.10 & & & \\
\hline 17 & 17.14 & 17.14 & 17.14 & 17.14 & 17.14 & $\begin{array}{l}17.14 \\
17.16 \\
17.17 \\
\end{array}$ & 17.14 & 17.14 & 17.6 & 17.19 & 17.14 \\
\hline
\end{tabular}


Pursuing sound management of chemicals and waste (12.4) helps to reduce the number of illnesses generated by hazardous chemicals and air, water, and soil pollution and contamination (3.9); to improve water quality by reducing dumping and minimising hazardous chemicals (6.3); and to reduce the environmental impact on cities (11.6). Reducing waste generation (12.5) is also linked to increasing water recycling (6.3) as well as to improving energy efficiency (7.3), to increasing global resource efficiency in consumption and production (8.4) and to reducing marine debris (14.1).

Encouraging companies to adopt sustainable practices (12.6) refers not only to production processes but also to social and environmental aspects of sustainability, as well as other strategies. These practices include ensuring sustainable food production systems (2.4), reducing hazardous chemicals and air, water and soil pollution and contamination, which in turn will improve health (3.9). Fostering these practices could imply increase technical training for employment and decent jobs (4.4), ending gender discrimination (5.1), protecting and restoring ecosystems (6.6), and supporting and strengthening the participation of local communities in improving water and sanitation management (6.b). Additionally, offering decent jobs (8.5); eradicating forced labour (8.7); promoting a safe and secure working environment (8.8), inclusive and sustainable industrialisation (9.2), and sustainable transport systems (11.2); protecting and safeguarding the world's cultural heritage (11.4); improving energy efficiency (7.3) and the sustainable use of oceans, seas and marine resources (14.1, 14.2, 14.3, 14.4 and 14.5); ensuring conservation, restoration and sustainable use of terrestrial and inland freshwater ecosystems (15.1) and sustainable management of forests (15.2); combating desertification and restoring degraded land and soil (15.3); and implementing transparency practices (16.6) and inclusive decisionmaking (16.7) are all sustainable practices that could be implemented by businesses.

Much the same is true of sustainable public procurement (12.7). Public agencies must consider many criteria when making purchasing decisions. In particular, these considerations encourage procurement practices that ensure sustainable food production systems or resilient agricultural practices (2.4), promote sound management of genetic diversity (2.5), reduce pollution and contamination (3.9), ensure quality education (4.1), eliminate gender disparities in education (4.5), and ensure women's full and effective participation and equal opportunities (5.5), among other things.

Target 12.8 (information and awareness) is linked to ensuring that all learners acquire the knowledge and skills needed to promote sustainable development (4.7), and to improving education, awareness-raising and human and institutional capacity with respect to climate change mitigation, adaptation, impact reduction and early warning (13.3). In parallel, it would be facilitated by promoting the empowerment of women 
(5.5), access to information and communications technology (9.c), and public access to information (16.10).

Supporting developing countries to strengthen their scientific and technological capacity to move towards sustainable CPPs (12.a) could ensure that people in those countries have access to basic services and to appropriate technologies (1.4); could enhance agricultural productive capacity in developing countries (2.a), including through the use of water efficiency, wastewater treatment, and recycling and reuse technologies (6.a); could facilitate access to clean energy research and technology (7.a); could expand infrastructure and upgrade technology for supplying sustainable energy (7b); and therefore, could enable access to energy services (7.1), could increase the share of renewable energy (7.2) and could improve energy efficiency (7.3). This cooperation also could take the form of scholarships for enrolment in higher education, including information and communications technology, technical, engineering and scientific programmes (4.b), as well as increasing the supply of qualified teachers (4.c). Achieving Target 12.a also would contribute to enhancing scientific research, to upgrading the technological capabilities of industrial sectors, and to encouraging innovation (9.5 and 17.6); to facilitating sustainable and resilient infrastructure development (9.a); to increasing access to communication technologies (9.c); to increasing human settlements adopting and implementing integrated policies and plans for resource efficiency, mitigation and adaptation to climate change, resilience to disasters, and holistic risk management (11.b); to supporting least developed countries in building sustainable and resilient buildings (11.c); to raising the capacity for effective climate change-related management (13.b); and to increasing scientific knowledge, to developing research capacity, and to transferring marine technology (14.b).

The development and implementation of tools to monitor sustainable development impacts for sustainable tourism (12.b) would contribute to various targets by enabling monitoring. In fact, these tools should be designed so as to take into account sustainable tourism that creates jobs and promotes local culture and products (8.9), protects the world's cultural and natural heritage (11.4), and increases economic benefits from the use of marine resources through sustainable tourism (14.7), and that also ends poaching and trafficking of protected species of flora and fauna (15.c).

Target 12.c (rationalise inefficient fossil-fuel subsidies) is linked to the aspiration of liberating resources to ensure access to basic services (1.4) such as energy for the poor or universal access to affordable, reliable and modern energy services (7.1). At the same time, the issue is also connected to the need to strengthen resilience and adaptive capacity with respect to climate-related hazards and natural disasters in all countries (13.1) and integrating climate change measures into national policies, strategies and planning (13.2). The transformation of the energy sector is crucial to making CPPs sustainable. 
Finally, advances in SDG 16 (Institutional dimension) and SDG 17 (Strengthening the means of implementation) will be crucial to move towards sustainable CPPs, and policy coherence, in particular.

\section{CONCLUSIONS}

The SDGs have elicited much enthusiasm and multiple initiatives to foster SD. Nevertheless, progress in their implementation has been limited and slow, particularly in areas such as Sustainable Consumption and Production (SDG 12), which is a crucial aspect of sustainable development.

Changing current CPPs will entail transforming society. On the one hand, production processes will need to dovetail with the functioning of socio-ecological systems, while on the other hand, consumers will have to be aware and well informed, supporting sustainable business models through their purchasing decisions and behaviours. The article uses the European conceptualisation of the $\mathrm{CE}$ to reflect on the transformation that attaining SDG 12 will entail. The CE pursues the transition from a linear economy to one in loops of value generation, requiring producers to become stewards of the planet and to embrace change to comprehensively redesign production processes in line with a systemic perspective.

The analysis of the targets of this goal shows a different reality. Fundamentally, these targets are a general call to follow sustainable business practices but without an integrated approach. In fact, the main one makes reference to the 10 Year Framework of Programmes on Sustainable Consumption and Production, which is very loosely defined, involving voluntary collaboration initiatives, and has not shown significant progress since its approval in 2012. At the same time, it does not involve consumers as key actors in the attainment of this goal when, in fact, there are already interesting and positive actions being taken by consumers around the world. The role of the media is also ignored, despite its great power to foster change in CPPs.

Therefore, we can say that SDG 12 suffers from the same weaknesses as most of the Agenda 2030. The study of the indicators for each target has not proved to be more encouraging. On the contrary, it has confirmed how hard it will be to deal with the main drivers or causes of the severe environmental and social crises currently facing the world, since the indicators mainly measure the state of the problem. Indications as to how to improve the situation are too general. A look at the 2018 SVR corroborates the lack of monitoring tools as well as the weakness of the existing ones. The scant data available speaks of little progress and not in the right direction.

The interlinkages of SDG 12 with most of the other goals confirm that the advancement in sustainable CPPs could contribute to attaining the rest of the targets, while attaining other targets would foster the achievement of SDG 12. Therefore, the need to advance simultaneously in all areas is also clear. 
A revision of the targets and the indicators with the aim of making them address the drivers of the problems instead of the pressures they cause would significantly boost SD. We also need not only clear definitions of CPPs, but more strategic and profound change.

All stakeholders are called to play an active role in achieving meaningful progress. Evidently, in order to bridge the existing gaps that prevent SCP, technical and social innovation is required. Effective participation in decision-making, policy coherence and transformative financing are needed, as well as the right incentives to boost the transition to a humanised CE. Integrating sustainability-related issues into study plans, including sustainable forms of production and consumption, is a major challenge.

Meanwhile, international cooperation would contribute to disseminating the advances required to speed up the process in the different areas of the world, adapting each target to the conditions of the particular context. If we are really committed to leaving no one behind, as the Agenda 2030 states, the transformation of society required by sustainable CPPs needs to be embraced.

\section{AUTHOR CONTRIBUTIONS}

We have both, SG and IP, contributed to the article. SG and IP have designed the study and carried out the literature review. SG and IP have analysed the data and SG elaborated the tables.

\section{CONFLICTS OF INTEREST}

The authors declare that there is no conflict of interest.

\section{REFERENCES}

1. United Nations. Transforming our world: The 2030 agenda for sustainable development. New York (US): United Nations; 2015.

2. United Nations General Assembly. United Nations Millennium Declaration. New York (US): United Nations General Assembly; 2000. A/RES/55/2.

3. Río Declaration on Environment and Development. In: United Nations Conference on Environment and Development/UNCED; 1992 Jun 3-14; Río de Janeiro, Brazil.

4. United Nations. The Millennium Development Goals Report. New York (US): United Nations; 2015.

5. UN. ECOSOC. Special Edition: Progress towards the Sustainable Development Goals Report of the Secretary-General. Advanced unedited version. New York (US): United Nations; 2019.

6. Bengtsson M, Alfredsson E, Cohen M, Lorek S, Schroeder P. Transforming systems of consumption and production for achieving the sustainable development goals: moving beyond efficiency. Sustain Sci. 2018;13:1533-47. doi: 10.1007/s11625-018-0582-1 
7. Bauer B, Watson D, Gylling AC. Sustainable Consumption and Production: An Analysis of Nordic Progress towards SDG 12 and the way ahead. Copenhagen (Denmark): Nordic Council of Ministers; 2018.

8. SDSN/Bertelsmann Stiftung. Global responsibilities implementing the goals. SDG INDEX AND DASHBOARDS REPORT 2018. Gütersloh (Germany): SDSN/Bertelsmann Stiftung; 2018. Available from: https://s3.amazonaws.com/ sustainabledevelopment.report/2018/2018 sdg index and dashboards repo rt.pdf. Accessed 2019 May 26.

9. SDSN/Bertelsmann Stiftung. Sustainable Development Report 2019. Transformations to achieve the SDGs. Includes the SDGs INDEX AND DASHBOARDS REPORT 2019. Gütersloh (Germany): SDSN/Bertelsmann Stiftung; 2019.

10. Spangenberg J. Hot Air or Comprehensive Progress? A Critical Assessment of the SDGs. Sustain Dev. 2017;25:311-21. doi: 10.1002/sd.1657

11. Naredo JM. Raíces económicas del deterioro ecológico y social. Más allá de los dogmas. Madrid (Spain): Siglo XXI; 2006. Spanish.

12. Floro MS. The Crises of Environment and Social Reproduction: Understanding their linkages. Washington, D.C. (US): Department of Economics, American University; 2012. p. 175-97.

13. IUCN-UNEP-WWF. World Conservation Strategy: Living Resource Conservation for Sustainable Development. Gland (Switzerland): IUCN; 1980.

14. Drexhage J, Murphy D. Sustainable Development: From Brundtland to Río 2012. Background paper prepared for the consideration of the High-Level Panel on Global Sustainability, at its first meeting, 19 September 2010. New York (US): United Nations; 2010.

15. Baker S, Kousis M, Richardson D, Young S. The politics of sustainable development. Theory, policy and practices within the European Union. New York (US): Routledge; 2002.

16. Redclift M. Sustainable development (1987-2005): an oxymoron comes of age. Sustain Dev. 2005;13(4):212-27. doi: 10.1002/sd.281

17. Boulding KE. The Economics of the coming spaceship earth. In: Jarrett $\mathrm{H}$, editor. Environmental Quality in a Growing Economy. Baltimore (US): Resources for the Future/Johns Hopkins University Press; 1966. p. 3-14.

18. Heinberg R. Peak everything: waking up to the century of declines. Gabriola Island (Canada): New Society Publishers; 2010.

19. Braungart M, McDonough W. Cradle to Cradle: Remaking the Way We Make Things. New York (US): North Point Press; 2002.

20. Stahel W, Reday G. Jobs for Tomorrow, the potential for substituting manpower for energy. Brussels (Belgium): Vantage Press; 1976.

21. Pearce DW, Turner RK. Economics of natural resources and the environment. Baltimore (US): Johns Hopkins University Press; 1990.

22. Reike D, Vermeulen W, Witjes S. The circular economy: New or refurbished as CE 3.0?-Exploring controversies in the conceptualization of the circular economy through a focus on history and resource value retention options. Resour Conserv Recy. 2018;135:246-64. 
23. European Commission. Scoping study to identify potential circular economy actions, priority sectors, material flows and value chain. European Commission. Luxembourg (Luxembourg): Publications Office of the European Union; 2014.

24. Berkes F, Folke C. Linking Social and Ecological Systems: Management Practices and Social Mechanisms for Building Resilience. New York (US): Cambridge University Press; 1998.

25. Young O, Berkhout F, Gallopin GC, Janssen MA, Ostrom E, Van Der Leeuwd S. The globalization of socio-ecological systems: An agenda for scientific research. Global Environ Change. 2006;16;304-16.

26. Nilsson M, Griggs D, Visbeck M. Policy: Map the interactions between sustainable development goals. Nature. 2016;534:320-2. doi: 10.1038/534320a

27. Pradhan P, Costa L, Rybski D, Lucht W, Krop JP. A Systematic Study of Sustainable Development Goal (SDG) Interactions. Earth's Future. 2017;5:1169-79. doi: 10.1002/2017EF000632

28. UNEP. Sustainable Consumption and Production: A Handbook for Policy Makers. Nairobi (Kenya): UNEP; 2015.

29. UNSTATS. Tier Classification for Global SDG Indicators. New York (US): UNSD; 22 May 2019. Available from: https://unstats.un.org/sdgs/files/Tier Classification of SDG Indicators 22 May 2019 web.pdf. Accessed 2019 May 30.

30. Gobierno de España. Spain's Report for the 2018. Voluntary National Review. Madrid (Spain): Gobierno de España; 2018. Available from: https://sustainabledevelopment.un.org/content/documents/203295182018 V NR Report Spain EN ddghpbrgsp.pdf. Accessed 2019 May 3.

31. SDG 12: Responsible consumption and production. Ensure sustainable consumption and production patterns. Available from: https://ec.europa.eu/eurostat/statistics-explained/index.php/SDG_12 Responsible consumption and production. Accessed 2019 Jun 1.

32. UN/HIGH-LEVEL POLITICAL FORUM ON SUSTAINABLE DEVELOPMENT. The 10 Year Framework of Programmes on Sustainable Consumption and Production Patterns. New York (US): United Nations; 2014.

33. Ellen MacArthur Foundation. Growth Within, A circular economy vision for a competitive Europe. Cowes (UK): Ellen MacArthur Foundation; New York (US): The McKinsey Center for Business and Environment; 2013.

34. Pla Julián I, Guevara S. Is circular economy the key to transitioning towards sustainable development? Challenges from the perspective of care ethics. Futures. 2019;105:66-7. doi: 10.1016/j.futures.2018.09.001

35. Eurostat. Available from: https://ec.europa.eu/eurostat/web/circulareconomy/indicators. Accessed 2019 Jun 12.

36. Searchinger T, Hanson C, Ranganathan J, Lipinski B, Waite R, Winterbottom $\mathrm{R}$, et al. Creating a sustainable food future. A menu of solutions to sustainably feed more than 9 billion people by 2050. World resources report 2013-14: interim findings. Washington, D.C. (US): World Resources Institute; 2014. 
37. European Commission. Public Procurement for a Circular Economy. Good practice and guidance. Brussels (Belgium): European Union; 2017.

How to cite this article:

Guevara S, Pla Julián I. Sustainable Consumption and Production: A Crucial Goal for Sustainable DevelopmentReflections on the Spanish SDG Implementation Report. J Sustain Res. 2019;1:e190019. https://doi.org/10.20900/jsr20190019 